\title{
Physicochemical, microbiological and sensory evaluation of a bioactive food blend
}

\author{
Rosângela dos Santos FERREIRA ${ }^{1,2 *}$, Priscila Aiko HIANE ${ }^{1,3}$, Rita de Cássia Avellaneda GUIMARÃES ${ }^{3}$,
} Maria Isabel Lima RAMOS ${ }^{1}$, Daniel Pecoraro DEMARQUE ${ }^{4}$, Júnia Elisa Carvalho de MEIRA ${ }^{5}$

\begin{abstract}
The potential of functional foods to decrease the risks of chronic non-communicable diseases has motivated the development of products with beneficial effects on fat and carbohydrate metabolism. The present study aimed at analyzing the physicochemical, microbiological, and sensory properties of a bioactive food blend developed to help the nutritional therapy provided to hypolipidemic and hyperglycemic patients with HIV/AIDS treated with antiretroviral therapy. The food blend was evaluated for moisture, protein, carbohydrate, fats, fixed mineral residue, total fiber content, and fatty acid composition, according to the standards established by the Instituto Adolfo Lutz. Food safety was assessed by microbiological analyses for Bacillus cereus, Salmonella spp, and coliforms. Sensory acceptance and intention to purchase were also evaluated. The food blend showed good nutritional potential, with low atherogenicity and thrombogenicity indexes, good macronutrient balance, and high energy value. The adoption of Good Manufacturing Practices (GMP) resulted in a product suitable for consumption. With respect to sensory aspects, the food blend showed satisfactory indexes of acceptability and promising marketing potential.
\end{abstract}

Keywords: functional foods; physicochemical; microbiological and sensory analysis; acceptability; nutritional proposal for HIV patients.

\section{Introduction}

Adequate feeding and nutrition can improve the effectiveness of Highly Active Antiretroviral Therapy (HAART), which is applied to patients with Acquired Immunodeficiency Syndrome (AIDS). It increases patient adhesion to treatment and helps control metabolic dysfunctions caused by medication. Nutritional interventions can be included in any programs for AIDS control and treatment (World Health Organization, 2003a).

In the 1990s, HAART increased the expectancy and quality of life of AIDS patients. However, although morbidity and mortality caused by opportunistic infections and neoplastic diseases decreased, other diseases have emerged, such as lipodystrophy, which involves complex endocrine-metabolic changes (Hadigan et al., 2001).

Some of the metabolic dysfunctions associated with lipodystrophy are increase in serum lipid levels, glucose intolerance, peripheral insulin resistance, and diabetes mellitus (Collins et al., 2000). In such cases, nutritional therapy with adequate inclusion of functional foods can improve the metabolic health of patients.

Given the potential of functional foods to reduce the risks of Chronic Non-Communicable Diseases (NCD), a number of studies have investigated the beneficial effects of their phytochemicals and bioactive components (Gamarano \& Fraige Filho, 2004). The physiological modulation of these foods includes hypocholesterolemic effects and the capacity to reduce the risk of atherosclerosis, stimulate the immunological system, and promote hypoglycemia (Gomes, 2002).

The adoption of healthy eating habits such as the inclusion of functional foods in daily meals requires behavioral changes. However, this is an important step in reducing the incidence of chronic-degenerative diseases. In this respect, it is the responsibility of health professionals to investigate the efficiency of functional foods and assist people in using these products for self-care (Basho \& Bin, 2010).

The consumption of functional foods that are available and affordable to consumers can be optimized (Prasad, 2007) if they are mixed with a bioactive food blend (BFB). This is exemplified by hypocholesterolemic and hypoglycemic ingredients such as brown flaxseed, oat bran, and textured soy protein (TSP).

Because of its bioactive compounds (Yuan et al., 1999), flaxseed (Linum usitatissimum) exhibits antiatherogenic and antithrombogenic effects (Prasad, 2007) decreasing the levels of Low Density Lipoproteins (LDL) and increasing those of High Density Lipoproteins (HDL). Fresh or toasted flaxseed and flaxseed oil show biological activity lowering glucose and triglyceride and cholesterol levels (Marques et al., 2011). This seed is a good source of polyunsaturated fatty acids (PUFA), especially $\alpha$-linolenic acid (ALA, C18:3n-3, $\omega-3$ ) and linoleic acid, in lower amounts (AL, C18:2n-6, $\omega-6$ ) (United States Departament of Agriculture, 2008). Flaxseed also contains other components with important body activities such as soluble and 
insoluble fibers and lignans (Cupersmid et al., 2012). Omega-3 fatty acids have protective effect against cardiovascular disease lowering plasma triglycerides (TG) by decreasing hepatic synthesis of VLDL-cholesterol (Falco et al., 2012).

Oat bran also contains high fiber content, mostly soluble fibers, which account for $50 \%$ of its composition; these fibers reduce LDL levels by increasing cholesterol absorption in the blood stream (Silva et al., 2003).

Soybean, in turn, (Glycine max L) is a legume that can be consumed in different forms, including textured soy. When regularly included in diet, it is associated to atherosclerosis prevention because it contains isoflavones and phytoestrogens, which act directly on serum lipids that participate in thrombus formation. Owing to its fiber content, soybean also plays an antioxidant role because it regulates bile acid activity related to sequestration of serum lipids (Anthony et al., 1996). Moreover, soybean fibers regulate glycemic status by delaying glucose absorption (Amaral, 2006).

The present study evaluated the chemical, microbiological, and sensory characteristics of a bioactive food blend, composed of functional ingredients developed to enhance the nutritional therapy of individuals with HIV/AIDS who developed dyslipidemia and hyperglycemia as side-effects of antiretroviral therapy due to the higher metabolic changes.

\section{Materials and methods}

\subsection{Preparation of the Bioactive Food Blend (BFB)}

The bioactive food blend (BFB) was produced according to the good manufacturing practice system (GMP) (Brasil, 1997; São Paulo, 2012). Ground flaxseed, oak bran, and textured soy protein were obtained from Natubom Alimentos Naturais ${ }^{\circledR}$ (Campo Grande, MS). For the production of the BFB (INPI - BR 1020130180025 -08/06/2013), the ingredients were mixed in the ratio of $1: 2: 1$ and homogenized.

A total of $720 \mathrm{~kg}$ of food was handled and packed in 600 units weighing $1.2 \mathrm{~kg}$, a 3-month supply of daily $40 \mathrm{~g}$ portions.

Six samples of raw materials and 20 units of the final product were randomly collected for physicochemical, microbiological, and sensory analyses.

\subsection{Proximate composition}

The proximate composition of the BFB was determined in triplicate, according to analytical methods adopted by the Adolfo Lutz Institute (Brasil, 2005). For moisture determination, the samples were oven-dried to constant weight at $105{ }^{\circ} \mathrm{C}$. Fixed mineral residue (ash) was determined by incineration in a muffle furnace at $550{ }^{\circ} \mathrm{C}$, and total lipid by Soxhlet extraction in ethyl ether. Protein levels were assessed by total nitrogen content, according to the micro-Kjeldahl method using a nitrogen-to-crude protein conversion factor of 6.25. Fiber content was determined by the enzymatic-gravimetric method. Carbohydrate levels were calculated by the difference: $100 \%$ - (moisture+ash+total lipid+protein+food fiber).

\subsection{Fatty acid composition}

Fatty acid composition was determined in the fat fraction of the BFB. To that end, after BFB oil was extracted according to Bligh \& Dyer (1959), it was saponified, esterified and transferred to hexane, as proposed by Hartman \& Lago (1973) and modified by Maia \& Rodriguez-Amaya (1993). Fatty acid methyl esters were analyzed using a Shimadzu GC-2010 chromatograph with AOC-5000 autoinjector and flame ionization detector (FID). A Restek Stabilwax-DA fused-silica bonded-phase column $(30 \mathrm{~m} \times 0.25 \mathrm{~mm} ; 0.25 \mu \mathrm{m})$ was used, with both injector and FID operating at $250^{\circ} \mathrm{C}$. Initial oven temperature was maintained at $80^{\circ} \mathrm{C}$ for $3 \mathrm{~min}$, raised to $140^{\circ} \mathrm{C}$ at a rate of $10^{\circ} \mathrm{C} / \mathrm{min}$, and then to $240{ }^{\circ} \mathrm{C}$ at $5^{\circ} \mathrm{C} / \mathrm{min}$, for $11 \mathrm{~min}$. The peaks of sample methyl ester identified by retention time on the column were compared to standard fatty acid methyl esters. The area correction factor was used for fatty acid quantification (Maia \& RodriguezAmaya, 1993; Holland et al., 1994).

\subsection{Nutritional quality index}

Nutritional quality, based on BFB fatty acid composition, was assessed by 5 different indexes. The atherogenic index (AI) (Equation 1) and the thrombogenic index (IT) (Equation 2) considered the levels of monounsaturated fatty acids (MUFA), according to Ulbricht \& Southgate (1991). The hypocholesterolemic: hypercholesterolemic ratio $(\mathrm{HH})$ (Equation 3) was calculated according to Santos-Silva et al. (2002). The other indexes determined were PUFA:SFA (polyunsaturated:saturated fatty acid) and $\omega 6: \omega 3$ ratios.

$$
\begin{aligned}
& \mathrm{AI}=\frac{\mathrm{C}_{12: 0}{ }^{+4} \times \mathrm{C}_{14: 0}+\mathrm{C}_{16: 0}}{\sum_{\text {MUFA }}+\sum_{\omega 6}+\sum_{\omega 3}} \\
& \mathrm{TI}=\frac{\mathrm{C}_{14: 0}+\mathrm{C}_{16: 0}+\mathrm{C}_{18: 0}}{0.5 \times \sum_{\text {MUFA }}+0.5 \times \sum_{\omega 6}+3 \times \sum_{\omega 3}} \\
& \mathrm{HH}=\frac{\mathrm{C}_{18: 1 \mathrm{cis} 9}+\mathrm{C}_{18: 2 \omega 6}+\mathrm{C}_{20: 4 \omega 6}+\mathrm{C}_{18: 3 \omega 3}+\mathrm{C}_{20: 5 \omega 3}+\mathrm{C}_{22: 5 \omega 3}+\mathrm{C}_{22: 6 \omega 3}}{\mathrm{C}_{14: 0}+\mathrm{C}_{16: 0}}
\end{aligned}
$$

\section{Microbiological analyses}

Microbiological analyses were carried out to detect the presence of Bacillus cereus, Salmonella sp and Coliforms at 45 ${ }^{\circ} \mathrm{C}$ in the raw materials and final products. These analyses are recommended by Resolution-RDC no. 12 of January 2, 2001, established by the National Agency of Sanitary Surveillance (ANVISA) of the Ministry of Health (Brasil, 2001), which regulates the processing of flours, pasta, and bakery products (for industrialization and packing) in bar and other forms, with or without additives.

The tests were conducted according to the methods proposed by the American Public Health Association, which is described in the Compendium of Methods for the Microbiological Examination of Foods (Vanderzant \& Splittstoesser, 1992). 


\subsection{Sensory analysis}

Acceptance tests were conducted at the Food Technology and Public Health Division of the Center of Biological Sciences and Health of the Federal University of Mato Grosso do Sul. One hundred untrained volunteers, male and female students and staff of UFMS, aged 18 to 60 years, took part in the study.

The BFB, prepared in three different forms (porridge, smoothie, and soup), was provided to the testers in individual portions (plastic cups). The testers also received water to drink between tests and were asked to fill out an evaluation card.

BFB acceptance was evaluated using a 9-point hedonic scale ranging from 1 (I dislike extremely) to 9 (I like extremely). Preparations that were given a score of at least 6 points (I liked slightly) were considered accepted. The testers also indicated their intention to purchase using a 5-point scale ranging from "I definitely would buy" to "I definitely would not buy" (Dutcosky, 2007).

The acceptability index (AI) was calculated as shown in Equation 4.

$\mathrm{AI}(\%)=\mathrm{A} \times 100 / \mathrm{B}$

where $\mathrm{A}$ is the mean score and $\mathrm{B}$ is the maximum score attributed to the product. $\mathrm{AI} \geq 70 \%$ can be considered a satisfactory result (Monteiro, 1984; Dutcosky, 2007).

The present study was approved by the UFMS Research Ethics Committee, under protocol number 1630 of October 20, 2009. All participants signed a Consent form.

\subsection{Statistical analysis}

Data were analyzed using Statistica Software 12 and oneway analysis of variance complemented by the Tukey test. The significance level was set at 0.05 (ANOVA).

\section{Results and discussion}

\subsection{Proximate composition}

The BFB contained high protein, fat, carbohydrate, and energy levels. Since BFB is a test formulation, specifically to help control metabolism dysfunctions in HIV/AIDS patients under HAART, the findings of this study cannot be accurately compared with those of other studies. However, the formulation proposed is close to that described for cereal bars.

The average proximate composition (\% wet basis) of the cereal bar formulation studied by Freitas \& Moretti (2006) was $15.31 \%$ protein, $74 \%$ carbohydrate, $4 \%$ total fiber, and $5.64 \%$ fat. In comparison, the BFB evaluated showed higher protein (24.27\%), fat (13.37\%), and fiber (7.98\%) content and lower carbohydrate (50.39\%) levels (Table 1).

The cereal bar formulated by Estévez et al. (1995), containing wheat germ, oat, and nuts, exhibited $16.5 \%$ protein and $3.3 \%$ fiber, values that are also lower than those found in the BFB. Lower nutrient levels were also detected in the cereal bar formulated by Peuckert et al. (2010) with textured soy protein, camu-camu, and chocolate, which contained $14.96 \%$ carbohydrate, $4.27 \%$ protein, $1.5 \%$ fat and $0.43 \%$ fiber.

Other studies have shown that the daily consumption of 3 to $15 \mathrm{~g}$ of soluble fiber, including guar, pectin, oat bran, and soy fiber, reduces blood cholesterol and glucose levels by $5-15 \%$ (Roy et al., 2000; Grizard et al., 2001).

\subsection{Fatty acid composition}

Table 2 shows the fatty acids composition of the BFB. PUFAs were the major constituents, totaling $60.41 \%$ of total fatty acids, in contrast to MUFAs and SFAs. Alpha-linolenic was the predominant fatty acid (30\%), followed by linoleic acid (27\%). These values result from flaxseed incorporation to $\mathrm{BFB}$, given that it is rich in $\omega-3$ and $\omega-6$ PUFA (Guimarães et al., 2013).

Palmitic acid (C16:0) was the primary SFA acid (11\%) and oleic acid the main MUFA (14\%).

Table 1. Proximate composition (mean $\pm \mathrm{sd} ; \mathrm{N}=3$ ) of the Bioactive Food Blend (BFB) ${ }^{1}$.

\begin{tabular}{|c|c|}
\hline Components & Content (g.100g-1 of BFB) \\
\hline Moisture & $0.65 \pm 0.032$ \\
\hline Protein & $24.27 \pm 0.381$ \\
\hline Total lipids & $13.37 \pm 0.347$ \\
\hline Fixed mineral residue & $3.34 \pm 0.013$ \\
\hline Total fiber & $7.98 \pm 0.23$ \\
\hline Carbohydrate & $50.39^{2}$ \\
\hline Total energy value (kcal.100g $\left.\mathrm{g}^{-1}\right)$ & 335.25 \\
\hline
\end{tabular}

Table 2. Fatty acid content (mean $\pm s d, N=2)$ in the fat portion of the bioactive food blend ( $\%$ of total fatty acids identified).

\begin{tabular}{lc}
\hline Fatty Acid & Content $(\%)$ \\
\hline Saturated (SFA) & \\
Caproic (C6:0) & $1.40 \pm 0.04$ \\
Caprylic (C8:0) & $3.47 \pm 0.69$ \\
Myristic (C14:0) & $1.20 \pm 0.02$ \\
Pentadecanoic (C15:0) & $1.25 \pm 0.03$ \\
Palmitic (C16:0) & $10.59 \pm 0.35$ \\
Stearic (C18:0) & $2.44 \pm 0.66$ \\
Arachidic (C20:0) & $1.65 \pm 0.05$ \\
Lignoceric (C24:0) & $1.32 \pm 0.03$ \\
TOTAL SFA & 23.13 \\
Monounsaturated (MUFA) & \\
Pentadecenoic (C15:1) & $2.66 \pm 0.67$ \\
Oleic (C18:1 $\omega-9)$ & $13.92 \pm 0.23$ \\
TOTAL MUFA & 16.45 \\
Polyunsaturated (PUFA) & \\
Linoleic (C18:2 $\omega-6)$ & $27.02 \pm 1.02$ \\
Alpha-linolenic (C18:3 $\omega-3)$ & $29.66 \pm 3.51$ \\
Eicosadienoic (C20:2 $\omega-6)$ & $1.42 \pm 0.04$ \\
Eicosatrienoic (C20:3 $\omega-6)$ & $1.17 \pm 0.01$ \\
Arachidonic (C20:4 $\omega-6)$ & $1.43 \pm 0.05$ \\
\hline TOTAL PUFA & 60.41 \\
& \\
\hline
\end{tabular}


The nutritional quality of the BFB oil assessed by different indexes is shown in Table 3. In general, these indexes indicate a good fatty acid balance due to the addition of flaxseed to the product.

The PUFA/SFA ratio is one of the main parameters used to assess the nutritional quality of the lipid fraction of foods (Romero et al., 2013). Nutritional guidelines recommend a PUFA/SFA ratio above 0.4 (World Health Organization, 2003b). Nevertheless, other studies have shown that this ratio must be considered together with the $\omega 6: \omega 3$ ratio since beneficial effects of $\omega 6$ on health are produced only when the PUFA/SFA ratio is above 1.5. (Romero et al., 2013).

Diets with high PUFA/SFA ratio are considered healthy because of their potential to decrease blood cholesterol. In the fat fraction extracted from the $\mathrm{BFB}$, the ratio was 2.6, indicating that this food may promote hypocholesterolemia.

The $\omega 6: \omega 3$ ratio is used to evaluate the nutritional value of the lipid fraction of foods; to prevent cardiovascular diseases, it is recommended that it be kept below 4.0 (United Kingdom, 1994; Williams, 2000), and in the BFB tested, it was 1.05. Other studies reported $\omega 6: \omega 3$ ratio of 0.31 in flaxseed oil (Guimarães et al., 2013), 8.07 in salamin (dry cured and fermented sausage) (Romero et al., 2013), and 0.90-3.55 in seven freshwater fish species from the Brazilian Pantanal (Ramos Filho et al., 2010).

Indexes based on the functional effects of different fatty acids, such as AI, TI, and HH, were evaluated because they allow better evaluation of the nutritional quality of food lipids. $\mathrm{HH}$ is an important index because it considers the effects of fatty acids on cholesterol metabolism. High values of this ratio are desirable, and they were higher in the BFB analyzed (6.11) than that obtained for other seed and fish oils (Table 3 ). On the other hand, highly nutritional diets show low levels of AI and TI, which can be associated with the potential risk of developing cardiovascular diseases (Ulbricht \& Southgate, 1991). In the present study, the BFB exhibited an AI of 0.2 and TI of 0.13 , demonstrating the high quality of the product tested.

\subsection{Microbiological analyses}

As shown in Table 4, the results of the microbiological analyses of the raw materials and BFB met the requirements established by Brazilian legislation RDC 12/2001 of ANVISA (Brasil, 2001), except for flaxseed, which exhibited a Bacillus cereus count five times higher than the accepted levels. However, Granum \& Lund (1997) reported that the count of viable $B$. cereus cells must exceed $10^{5} \mathrm{CFU} / \mathrm{g}$ to cause diarrheic or emetic syndrome. Therefore, although the $B$. cereus count observed in the present study was above the limit established by legislation (Brasil, 2001), it does not indicate toxin production. Nevertheless, it is important to qualify suppliers because a single contaminated item of raw material can affect the entire production can compromise the entire production due to toxins produced by fungi and bacteria. These toxins are hazardous, but they may be not detected in the final product because they are present in very small quantities compared to other components of the formulation.

Flaxseed contamination reinforces the importance of rigorous quality control of raw materials, especially regarding storage conditions, so that the product offered complies with current sanitary standards. Another aspect regarding quality relies on the importance of adopting GMP. In the present study, it was crucial for ensuring the production of a high quality BFB, suitable for human consumption.

Bacillus cereus is a facultative aerobic bacterium that produces spores and is commonly found in soil, plants, and in a number of crude and processed foods. It can produce toxins such as enterotoxins, and, as such, it needs to be controlled in the food processing chain to guarantee food safety and integrity. In a study on seven commercial brands of brown flaxseed marketed

Table 3. Nutritional quality indexes of the fat fraction of the bioactive food blend, sesame oil, flaxseed oil, fish oil, and salamin.

\begin{tabular}{|c|c|c|c|c|c|}
\hline INDEX & $\begin{array}{c}\text { Bioactive compound } \\
\text { feed oil } \\
\end{array}$ & Sesame oil ${ }^{\star}$ & Flaxseed oil ${ }^{\star}$ & Fish oil (Jau ${ }^{* *}$ & Salamin $^{\star * *}$ \\
\hline $\begin{array}{l}\text { PUFA/SFA ratio } \\
\text { S }\end{array}$ & 2.61 & 0.79 & 5.24 & 0.27 & 0.46 \\
\hline$\omega 6 / \omega 3$ ratio & 1.05 & 97.80 & 0.31 & 2.14 & 8.07 \\
\hline Atherogenicity index (AI) & 0.20 & 0.69 & 0.07 & 0.62 & 0.50 \\
\hline Thrombogenicity index (TI) & 0.13 & 0.13 & 0.07 & 1.00 & 1.09 \\
\hline $\begin{array}{l}\text { Hypocholesterolemic: } \\
\text { hypercholesterolemic ratio } \\
(\mathrm{HH})\end{array}$ & 6.11 & 4.82 & 14.85 & 1.30 & -- \\
\hline
\end{tabular}

Table 4. Microbiological analyses of raw material and Bioactive Food Blend (BFB).

\begin{tabular}{lccc}
\hline & Coliforms at $45^{\circ} \mathrm{C}\left(\right.$ MPN. $\left.{ }^{-1}\right)$ & Bacillus cereus $\left(\mathrm{CFU} . \mathrm{g}^{-1}\right)$ & Salmonella sp (in $25 \mathrm{~g})^{\star *}$ \\
\hline Flaxseed & $2.2 \times 10^{2}$ & $2.6 \times 10^{4}$ & Absent \\
Oat Bran & $1.9 \times 10$ & Absent & Absent \\
Textured Soy Protein & Absent & $1.9 \times 10^{2}$ & Absent \\
BFB & $4.1 \times 10^{2}$ & $1.2 \times 10$ & Absent \\
RDC $12 / 2001^{*}$ & $5.0 \times 10^{2}$ & $5.0 \times 10^{3}$ & Absent \\
\hline
\end{tabular}

$\mathrm{MPN}=$ most probable number; $\mathrm{CFU}=$ colony forming units; ${ }^{*}$ upper limits established by the Brazilian legislation (Brasil, 2001); ${ }^{* *}$ presence-absence sampling. 
Table 5. Mean scores attributed to the BFB added to the different preparations.

\begin{tabular}{cc}
\hline Preparations & Scores $^{1}$ \\
\hline Porridge & $6.54^{\mathrm{b}}$ \\
Soup & $6.98^{\mathrm{a}}$ \\
Smoothie & $5.33^{\mathrm{b}}$ \\
\hline
\end{tabular}

${ }^{1}$ Equal superscript letters do not differ statistically $(p>0.05)$.

in Uberlândia-MG, Borges \& Deborah (2011) did not detect a B. cereus count above the limit established by RDC 12/2001 (Brasil, 2001). However, similar to the present study, Stelato et al. (2009) found that in the B. cereus count carried out in cereal bars, 5 samples were contaminated, and one non-light cereal bar exceeded the limit established by law.

Given that the viable Bacillus cereus cell count in ground flaxseed exceeded the acceptable limit and considering that the BFB tested was developed for people with HIV/AIDS, the participants in the study were instructed to cook this product. The BFB must be cooked, either in hot meals (such as soups, beans, meat sauces, and porridge) or before being added to cold preparations such as smoothies and yogurt. This procedure can reduce microbial and toxin load since Bacillus cereus toxins are thermolabile and can be easily inactivated by heating at $56^{\circ} \mathrm{C}$ for $10 \mathrm{~min}$ (Margosch et al., 2005), and viable cells are destroyed if subjected to $62.5^{\circ} \mathrm{C}$ for $15 \mathrm{~min}$ (Drobniewski, 1993). We underscore, however, that rigorous sanitary control of food production and storage conditions is indispensable because certain toxins are thermostable and need to be subjected to $121^{\circ} \mathrm{C}$ for 90 min to be inactivated (Silva et al., 2007).

Bacillus cereus control through adequate refrigeration or heating (over $55^{\circ} \mathrm{C}$ ) is important to inhibit intense bacterial multiplication, especially in ready-to-eat foods. None of the products that are conducive to the proliferation of this pathogen must be kept between $15^{\circ}$ and $60^{\circ} \mathrm{C}$ for more than $2-3 \mathrm{~h}$ (Leitão et al., 1987; Batista \& Venâncio, 2003).

\subsection{Sensory analysis}

BFB acceptance was evaluated in 3 preparations (Table 5). Soup was the most accepted, and as reported by the testers, its flavor was the main reason for purchasing and consuming the product (Lima et al., 2010; Barbosa \& Coelho, 2008; Munhoz et al., 2014). The acceptability index (AI) for BPBbased soup was $75 \%$, indicating high marketing potential. Peuckert et al. (2010) found an AI above $70 \%$ for cereal bars added with textured soy protein and camu-camu (Myrciaria dubia). Similar to the results of the present study, Costa et al. (2005) found an AI of $78 \%$ in bars with manioc residue.

\section{Conclusion}

The BFB developed shows high nutritional potential because it is rich in PUFA, especially a-linolenic acid. It exhibits low atherogenicity and thrombogenicity indexes, showing a potential contribution to the control of atherosclerotic diseases. The BFB evaluated also exhibited high protein and fiber content, reinforcing its nutritional value.
The microbiological analysis of raw material showed that, although textured soy protein and oat bran were in compliance with current legislation, the Bacillus cereus count in ground flaxseed exceeded the upper limit. Nevertheless, the final product was suitable for consumption. Monitoring the final product is therefore essential to prevent posing health risks to consumers, especially immunologically vulnerable individuals.

Sensory evaluation of the BFB produced indicates that it has good marketing potential. In addition, the acceptability index (AI) for the salty preparation (soup), was above $70 \%$, which is considered a satisfactory level.

The BFB produced proved suitable for inclusion in the diets of HIV-positive patients. It can also be used as nutritional complement for health maintenance or to treat patients with other disorders such as hypercholesterolemia, hypertriglyceridemia, intolerance to glucose, and diabetes.

\section{Acknowledgements}

The authors are grateful for the financial support provided by Fundação de Apoio ao Desenvolvimento do Ensino, Ciência e Tecnologia, Mato Grosso do Sul state.

\section{References}

Amaral, V. M. G. (2006). A importância da soja como alimento funcional para qualidade de vida e saúde (Dissertação de mestrado). Faculdade de Engenharia Mecânica, Universidade Estadual de Campinas, Campinas.

Anthony, M. S., Clarkson, T. B., \& Hughes, C. L. (1996). Soybean isoflavones improve cardiovascular risck factors affecting the reproductive system of peripubertal rhesus monkeys. Journal of Nutrition, 126(1), 43-50. PMid:8558324.

Barbosa, E. S. P., \& Coelho, N. R. A. (2008). Elaboração e avaliação sensorial de barra de cereais de linhaça. Revista de Processos Químicos, 2(4), 62-7.

Basho, S. M., \& Bin, M. C. (2010). Propriedades dos alimentos funcionais e seu papel na prevenção e controle da hipertensão e diabetes. Interbio, 4(1), 48-58.

Batista, P., \& Venâncio, A. (2003). Os perigos para a segurança alimentar no processamento de alimentos. Guimarães: Forvisão Consultoria em Formação Integrada.

Bligh, E. G., \& Dyer, W. J. (1959). A rapid method of total lipid extraction and purification. Canadian Journal of Biochemistry and Physiology, 37(8), 911-917. PMid:13671378. http://dx.doi. org/10.1139/059-099

Borges, C. B. F., \& Deborah, S. B. (2011). Qualidade microbiológica da linhaça (Linum usitatissimum L.) in natura comercializada no município de Uberlândia - MG. Enciclopédia Biosfera. Centro Científico Conhecer, 7(12), 1-8.

Brasil. Ministério da Saúde. (1997, 1 de Agosto). Regulamentação técnica sobre as condições higiênico-sanitárias e de boas práticas de fabricação para estabelecimentos produtores/industrializadores de alimentos (Portaria no 326, de 30 de julho de 1997). Diário Oficial da União.

Brasil. Ministério da Saúde. Agência Nacional de Vigilância Sanitária. (2001, 10 de Janeiro). Dispóe sobre o regulamento técnico sobre padrões microbiológicos para alimentos (Resolução RDC n 12 , de 02 de janeiro de 2001). Diário Oficial da União. 
Brasil. Ministério da Saúde. Agência Nacional de Vigilância Sanitária. (2005). Métodos físico-químicos para análises de alimentos. Brasília. $1018 \mathrm{p}$.

Collins, E., Wagner, C., \& Wamsley, S. (2000). Psychosocial impact of the lipodistrophy syndrome in HIV infection. AIDS Reader, 10(9), 546-551. PMid:11019453.

Costa, L. A., Bramorski, A., Silva, M. C., Teixeira, E., \& Amboni, R. D. M. C. (2005). Desenvolvimento de alimento em barra à base de resíduo da fabricação de farinha de mandioca. Alimentos e Nutrição, 16(4), 389-396.

Cupersmid, L., Fraga, A. P. R., Abreu, E. S., \& Pereira, I. R. O. (2012). Linhaça: composição química e efeitos biológicos. e-Scientia, 5(2), 33-40.

Drobniewski, F. A. (1993). Bacillus cereus and Related Species. Clinical Microbiology Reviews, 6(4), 324-338. PMid:8269390 PMCid:PMC358292.

Dutcosky, S. D. (2007). Análise sensorial de alimentos. Curitiba: Champagnat. $123 \mathrm{p}$.

Estévez, A. M., Escobar, B., Vázquez, M., Castillo, E., Araya, E. \& Zacarías, I. (1995). Cereal and nut bars, nutritional quality and storage stability. Plant Foods for Human Nutrition, 47(4), 309-317. PMid:8577648. http://dx.doi.org/10.1007/BF01088268

Falco, M., Castro, A. C. O., \& Silveira, E. A. (2012). Terapia nutricional nas alterações metabólicas em pessoas vivendo com HIV/aids. Revista de Saúde Pública, 46(4), 737-746. PMid:22782126. http:// dx.doi.org/10.1590/S0034-89102012000400019

Freitas, D. G. C., \& Moretti, R. H. (2006). Caracterização e avaliação sensorial de barra de cereais funcional de alto teor protéico e vitamínico. Ciência e Tecnologia de Alimentos, 26(2), 318-324. http:// dx.doi.org/10.1590/S0101-20612006000200014

Gamarano, L., \& Fraige Filho, F. (2004). Alimentos funcionais no tratamento do Diabetes Mellitus. Qualidade em Alimentação: Nutrição, (19), 20-21.

Gomes, G. B. (2002). Alimentos funcionais e doença aterosclerótica. Qualidade em Alimentação: Nutrição, (13), 16-17.

Granum, P. E., \& Lund, T. (1997). Bacillus cereus and its food poisoning toxins. FEMS Microbiology Letters, 157(2), 223-228. PMid:9435100. http://dx.doi.org/10.1111/j.1574-6968.1997.tb12776.x

Grizard, D., Dalle, M., \& Barthomeuf, C. (2001). Changes in insulin and cortiosterone levels may partly mediate the hypolipidemic effect of guar gum and low-molecular weight pectin in rats. Nutrition Research, 21(8), 1185-1190. http://dx.doi.org/10.1016/ S0271-5317(01)00316-5

Guimarães, R. C. A., Macedo, M. L. R., Munhoz, C. L., Filiu, W., Viana, L. H., Nozaki, V. T., \& Hiane, P. A. (2013). Sesame and flaxseed oil: nutritional quality and effects on serum lipids and glucose in rats. Food Science and Technology, 33(1), 209-217.

Hadigan, C., Meigs, J. B., Corcoran, C., Rietschel, P., Piecuch, S., Basgoz, N., Davis, B., Sax, P., Stanley, T., Wilson, P. W. F., D’Agostino, R. B., \& Grinspoon, S. (2001). Metabolic abnormalities and cardiovascular disease risk factors in adults with human immunodeficiency virus infection and lipodystrophy. Clinical Infectious Diseases, 32(1), 130139. PMid:11118392. http://dx.doi.org/10.1086/317541

Hartman, L., \& Lago, R. C. A. (1973). A rapid preparation of fatty acid methyl from lipids. Laboratory Practice, 22(3), 475-473. PMid:4727126.

Holland, B., Welch, A. A., Unwin, I. D., Buss, D. H., Paul, A. A., Southgate, D. A. T. (1994). The composition of foods. Cambridge: McCance and Widdowson's. p. 8-9.
Leitão, M. F. F., Hagler, L. C. S. M., Hagler, A. L., \& Menezes, T. J. B. (1987). Tratado de Microbiologia (Vol. 1). São Paulo: Manole.

Lima, J. C. R., Freitas, J. B., Czeder, L. P., Fernandes, D. C., \& Naves, M. M. V. (2010). Qualidade microbiológica, aceitabilidade e valor nutricional de barras de cereais formuladas com polpa e amêndoa de baru. Boletim do Centro de Pesquisa e Processamento de Alimentos, 28(2), 331-343.

Maia, E. L., \& Rodriguez-Amaya, D. B. (1993). Avaliação de um método simples e econômico para a metilação de ácidos graxos com lipídios de diversas espécies de peixes. Revista do Instituto Adolfo Lutz, 53(1-2), 27-35.

Margosch, D., Moravek, M., Gänzle, M. G., Märtlbauer, E., Vogel, R. F., \& Ehrmann, M. A. (2005). Effect of pressure and heat on bacterial toxins. Food Technology and Biotechnology, 43(3), 211-217.

Marques, A. C., Hautrive, T. P., Moura, G. B., Callegaro, M. G. K., Hecktheuer, L. H. R. (2011). Efeito da linhaça (Linum usitatissimum L.) sob diferentes formas de preparo na resposta biológica em ratos. Revista de Nutrição, 24(1), 131-141. http://dx.doi.org/10.1590/ S1415-52732011000100013

Monteiro, C. L. B. (1984). Técnicas de avaliação sensorial (2. ed.). Curitiba: Universidade Federal do Paraná, CEPPA. p. 101.

Munhoz, C. L., Guimarães, R. C. A., Nozaki, V. T., Sanjinez-Argandoña, E. J., Hiane, P. A., \& Macedo, M. L. R. (2014). Preparation of a cereal bar containing bocaiuva: physical, nutritional, microbiological and sensory evaluation. Acta Scientiarum: Technology, 36(3), 553-560. http://dx.doi.org/10.4025/actascitechnol.v36i3.18561

Peuckert, Y. P., Viera, V. B., Hecktheuer, L. H. R., Marques, C. T., \& Rosa, C. S. (2010). Caracterização e aceitabilidade de barras de cereais adicionadas de proteína texturizada de soja e camu - camu (Myrciaria dubia). Alimentos e Nutrição, 21(1), 147-152.

Prasad, K. (2007). Dietary flax seed in prevention of hypercholesterolemic atherosclerosis. Atherosclerosis, 132(1), 69-76. http://dx.doi. org/10.1016/S0021-9150(97)06110-8

Ramos Filho, M. M., Ramos, M. I. L., Hiane, P. A., \& Souza, E. M. T. (2010). Nutritional value of seven freshwater fish species from the Brazilian Pantanal. Journal of American Oil Chemistry Society, 87(12), 1461-1467. http://dx.doi.org/10.1007/s11746-010-1639-1

Romero, M. C., Romero, A. M., Doval, M. M., \& Judis, M. A. (2013). Nutritional value and fatty acid composition of some traditional Argentinean meat sausages. Food Science and Technology, 33(1), 161-166.

Roy, S., Veja-Lopez, S., \& Fernandez, M. L. (2000). Gender and hormonal status affect the hypolipidemic mechanisms of dietary soluble fiber in guinea pigs. Journal of Nutrition, 130(3), 600-607. PMid:10702591.

Santos-Silva, J., Bessa, R. J. B., \& Santos-Silva, F. (2002). Effect of genotype, feeding system and slaughter weigt on the quality of light lambs. II. Fatty acid composition of meat. Livestock Production Science, 77(2-3), 187-194. http://dx.doi.org/10.1016/S03016226(02)00059-3

São Paulo. Prefeitura do Município de São Paulo. Secretaria Municipal da Saúde. Coordenação de Vigilância em Saúde. (2012). Manual de boas práticas e manipulação de alimentos. São Paulo.

Silva, M. A. M., Barcelos, M. F. P., Sousa, R. V., Lima, H. M., Falco, I. R., Lima, A. L., \& Pereira, M. C. A. (2003). Efeito das fibras dos farelos de trigo e aveia sobre o perfil lipídico no sangue de ratos Wistar. Ciência e Agrotecnologia, 27(6), 1321-1329. http://dx.doi. org/10.1590/S1413-70542003000600017 
Silva, N., Junqueira, V. C. A., Silveira, N. F. A., Taniwaki, M. H., Santos, R. F. S., \& Gomes, R. A. R. (2007). Manual de métodos de análise microbiológica de alimentos. São Paulo: Varela. p. 345.

Stelato, M. M., Ramos, M. M., Possignolo, G. O., \& Srebernich, S.M. (2009). Pesquisa de bactérias em barras de cereais comercializadas em Campinas e região, SP. Higiene Alimentar, 23(178-179), 141-145.

Ulbricht, T. L. V., \& Southgate, D. A. T. (1991). Coronary heart disease: seven dietary factors. Lancet, 338(8773), 985-992. http://dx.doi. org/10.1016/0140-6736(91)91846-M

United Kingdom. Her Majesty's Stationer Office. Department of Health and Social Security. (1994). Nutritional aspects of cardiovascular disease (Report on Health and Social Subjects No. 46). London. p. 178.

United States Departament of Agriculture - USDA. (2008). National nutrient database for standard reference: release 20. Washington. Retrieved from http://www.nal.usda.gov/fnic/foodcomp/search
Vanderzant, C., \& Splittstoesser, F. (1992). Compendium of methods for the microbiological examination of foods (3th ed.). Washington: APHA. PMid:22059567.

Williams, C. M. (2000). Dietary fatty acids and human health. Annales de Zootechnie, 49(3), 165-180. http://dx.doi.org/10.1051/ animres:2000116

World Health Organization - WHO. (2003a). Nutrient requirements for people living with HIV/AIDS: reports of a technical consultation. Genebra. p. 31.

World Health Organization - WHO. (2003b). Diet, nutrition and the prevention of chronic diseases (Who Technical Report Series No. 916). Geneva. p. 87-88. Retrieved from http://whqlibdoc.who. int/trs/WHO_TRS_916.pdf

Yuan, Y. V., Rickard, S. E., \& Thompson, L. U. (1999). Short-term feeding of flaxseed or its lignan has minor influence on in vivo hepatic antioxidant status in young rats. Nutrition Research, 19(8), 1233-1243. http://dx.doi.org/10.1016/S0271-5317(99)00084-6 